\title{
Measuring ground subsidence in Hanoi city by radar interferometry
}

- Ho Tong Minh Dinh ${ }^{1}$

- Tran Quoc Cuong ${ }^{2}$

- Nguyen Duc Anh ${ }^{2}$

- Le-Toan Thuy ${ }^{3}$

${ }^{1}$ Institut national de Recherche en Sciences et Technologies pour l'Environnement et l'Agriculture (IRSTEA), UMR TETIS, Montepllier, France

${ }^{2}$ Institute of Geological Sciences-VAST, Hanoi, Vietnam

${ }^{3}$ Centre d'Etudes Spatiales de la Biosphere (CESBIO), Toulouse, France

(Manuscript Received on June $28^{\text {th }}, 2016$, Manuscript Revised on August 16 ${ }^{\text {th }}$,2016)

\begin{abstract}
The rapidly developing urbanization since the last decade of the $20^{\text {th }}$ century leads to the strong groundwater extraction, resulting in the subsidence phenomena in the Hanoi, Vietnam. Recent advances in the multi-temporal spaceborne SAR interferometry, especially with Persistent Scatters Interferometry (PSI) approach, is the robust remote sensing technique for measuring ground subsidence in large scale with millimetric accuracy. This work has presented an advanced PSI analysis, to provide unprecedented spatial extent and

Keywords: Hanoi, subsidence, PS/DS, Irstea TomoSAR platform

\section{INTRODUCTION}

In Vietnam, flooding becomes a serious problem as more frequent flooding happened both from regular and from extreme climatic events such as tropical storms and typhoons, particularly in Ho Chi Minh City and Hanoi [1]. In response to the flooding challenges, besides climate change adaptation, the knowledge of the

continuous temporal coverage of the subsidence in Hanoi City. The correlation between the reference leveling velocity and the estimated PSI result is $R^{2}=0.86$, and the root mean square error is 4.0 (mm/year), confirming their good agreement. The study shows that subsidence is most severe in the Haihung silt loam areas in the south of the city. The groundwater extraction resulting from urbanization and urban growth is mainly responsible for the subsidence.

ground subsidence such as their spatial extent and their temporal evolution is essential.

Ground subsidence induced by water overexploitation of underground reservoirs is a common problem happened in many cities over the word. In Vietnam, the rapid increase of ground water use started in late 1990s. This result in the water table has been lowering, leading to the subsidence of some areas. In
\end{abstract}

\section{Trang D2}


Hanoi, land subsidence at the rate of few centimeters per year can be measured at many groundwater pumping stations.

Multi-temporal Interferometry SAR (InSAR) approach [2,3] has already shown its ability in mapping ground deformation on a large spatial scale with short term data sampling rates. Particular in [3], a Maximum Likelihood Estimator based, offers a rigorous way to jointly exploit not only stable point-like scatterers (socalled permanent scatterers - PS) but also distributed scatterers (DS). Such increased number of identified PS/DS points on the ground results at an increased confidence of the ground motion, compared to the previous PS algorithm [3].

\section{METHOD}

The conventional spaceborne InSAR takes advantage of the geometry between two SAR acquisitions to obtain the interferometric phase, but this technique has issues relative to atmospheric, spatial and temporal decorrelations that cannot be efficiently eliminated resulting to not entirely reliable interferograms that represent the ground deformation [4]. This deficiency has been overcome by a specific analysis considering phase changes in a series of SAR images acquired at different times over the same region.

Let $d(r, x, b n)$ represent a generic Single Look Complex (SLC) image of the spaceborne data stack, where $(r, x)$ indicates the range and azimuth coordinates and bn is the normal baseline. We have [5]:

$d\left(r, x_{z} b_{n}\right)=\int s\left(x^{\prime}, y^{\prime}, z^{\prime}\right) f\left(r-R, x-x^{\prime}\right) \exp \left(j \varphi^{n}\right) d x^{\prime} d y^{\prime} d z^{\prime}$

where $\varphi^{n}=\frac{4 \pi}{\lambda} \mathbb{R}_{n}$ is the interferometric phase, $\mathbb{R}_{\mathrm{n}}=\mathbb{R}_{\mathrm{n}}\left(\mathbf{b}_{\mathrm{n}}, x^{\prime}, y^{\prime}, z^{\prime}\right)$ is the (zeroDoppler) distance between the target at ( $x^{\prime}, y^{\prime}, z^{\prime}$ ) and the n-th orbit acquisition, $s$ is the complex value scatterer of the target, $\lambda$ is the carrier wavelength, and $f(r, x)$ is the system pulse response function.

$\varphi^{\mathrm{n}}$ is composed of the phase components related to deformation, residual topography, atmosphere, and noise:

$\left.\varphi^{\mathrm{n}}=\varphi_{\text {defo }}+\varphi_{\text {ropo }}^{\mathrm{n}}+\varphi_{\text {acmo }}^{\mathrm{n}}+\varphi_{\text {mols }}^{\mathrm{n}}\right)$

where $\varphi_{\text {defo }}^{\mathrm{n}}$ is the deformation phase, $\varphi_{\mathrm{topo}}^{\mathrm{n}}$ is the residual topographic phase, $\varphi_{\text {atmo }}^{\mathrm{n}}$ is the atmospheric phase, and $\varphi_{\text {noise }}^{\mathrm{n}}$ is the phase noise. The goal is to estimate the deformation phase, which can be written as follows (assuming a constant velocity model):

$\varphi_{\mathrm{defo}}^{\mathrm{n}}=\frac{4 \pi \mathrm{t}_{\mathrm{n}}}{\lambda} \mathrm{v}$

where $\mathrm{v}$ is the mean deformation light of sight velocity of the target, and $t_{n}$ is the temporal baseline. The residual topographic phase is given as follows:

$\varphi_{\mathrm{top} 0}^{\mathrm{n}}=\frac{4 \pi b_{\mathrm{n}}}{\lambda \sin \theta \mathrm{R}_{\mathrm{n}}} \Delta \mathrm{h}$

where $\Delta \mathrm{h}$ is the residual topography, and $\theta$ is the local incidence angle. The atmospheric phase is the delay of the signal due to weather conditions. The phase noise is due to temporal decorrelation, mis-coregistration, uncompensated spectral shift decorrelation, orbital errors, and thermal noise. The main concept of the all multi-temporal InSAR techniques is the attempt to minimize the effects of the atmospheric phase and the phase noise to estimate the deformation phase (and the residual topographic phase) robustly.

Permanent/Persistent Scatters Interferometry (PSI) is the first attempt to give a formal framework to the problem of multitemporal InSAR [1]. Instead of analyzing the entire images, the analysis is based only on the selection of a number of highly coherent, temporally stable, point-like targets within the 
imaged scene, which can be identified by analyzing the amplitude stability of every pixel [1]. However, such process is likely to fail in areas where the initial PS selection, based on amplitude stability, does not suffice to cover the whole imaged scene, as it may be the case of non urban areas.

Several approaches have been presented in literature to perform SAR interferometric analysis over scenes where the PS assumption may not be retained, e.g. by considering Distributed Scatterers (DS). A number of these works share the idea to minimize the effect of target decorrelation by exploitating of a set of interferograms taken with the shortest temporal and/or spatial baselines possible (Small Baseline Subsets (SBAS)) [6]. This approach can be considered as the complement of the PSI approach.

In the work by [7] and [3], the estimation process of the residual topography and the deformation rate from not only PS but also DS targets, is split into two steps. In the first step, the Maximum Likelihood Estimation (MLE) is used that jointly exploits all $\mathrm{N}(\mathrm{N}-1) / 2$ interferograms available from $\mathrm{N}$ images, in order to squeeze the best estimates of the $\mathrm{N}-1$ interferometric phases. This step is known as name Phase Linking or Phase Triangulation [3]. Such step is very powerful for DS-based phase calibration in forest SAR tomography frame works, even with $\mathrm{N}=6$ images [8]. The computational burden of the first step is very low, but the same performance as the one step MLE can be approached only under the condition that the $\mathrm{N}(\mathrm{N}-1) / 2$ phases are estimated with sufficient accuracy, as it happens by exploiting a large estimation window and/or at high Signal To Noise Ratio. Once the first estimation step has yielded the estimates of the $\mathrm{N}-1$ interferometric phases, the second step is required to separate the contributions of the decorrelation noises from the parameters of interest as in PS processing.

In this work, we are in principle following the two steps approach in MLE frame work to exploit not only PS but also DS information for estimating the deformation. The reader is referred to [1] for the full descriptions of the processing chain. The results are processed by the Irstea TomoSAR platorm which offers SAR, InSAR and tomography processing.

The Irstea TomoSAR platform was created by D. Ho Tong Minh through the framework of BIOMASS mission $[8,9,10]$. The kernel of this platform supports the entire processing from SAR, Interferometry, Polarimetry, to Tomography (so called TomoSAR). The TomoSAR platform is currently deployed as a service as demand (http://ids.equipexgeosud.fr/tomosar-services).

\section{DATA}

Hanoi is located in the delta area of the Red River. The city is situated about $100 \mathrm{~km}$ from the Gulf of Tonkin. The water for domestic and industrial use in Hanoi comes from wells located within and around the city. The heavy pumping of groundwater has produced a serious settlement problem, which in turn has affected surface structures in the city of Hanoi.

The first SAR stack is from Japan Aerospace Exploration Agency ALOS PALSAR L-band 2007-2011. Two other X-band SAR stacks are Cosmos Skymed (CSK) and TerraSAR (TSX) for the period 2011-2014. Table 1 reports the detailed information.

\section{RESULTS}

Three data stacks were processed by using the PS/DS processing. In Fig.1, the averaged vertical velocity $(\mathrm{mm} / \mathrm{yr})$ map of these dataset is shown. Positive velocities (green colors) represent movement uplift; negative velocities (red colors) represent movement subsidence. 
TAP̈ OH́ PHAÜTREÅAKSON TAR̈ 19, SOKKA-2016

Table 1. SAR data information

\begin{tabular}{|c|c|c|c|c|c|c|c|c|}
\hline \multicolumn{3}{|c|}{ ALOS PALSAR } & \multicolumn{3}{|c|}{ TerraSAR-X } & \multicolumn{3}{|c|}{ Cosmos SkyMed } \\
\hline ID & Time & Bn [m] & ID & Time & Bn $[\mathrm{m}]$ & ID & Time & Bn [m] \\
\hline 1 & 02-Feb-2007 & -702 & 1 & 10-Apr-2012 & -42 & 1 & 27-May-2011 & -895 \\
\hline 2 & 20-Jun-2007 & -455 & 2 & 21-Apr-2012 & -24 & 2 & 05-Jul-2011 & -506 \\
\hline 3 & 05-Aug-2007 & -81 & 3 & 26-Jun-2012 & -133 & 3 & 15-Aug-2011 & 351 \\
\hline 4 & 20-Sep-2007 & -394 & 4 & 11-Sept-2012 & -384 & 4 & 22-Aug-2011 & 743 \\
\hline 5 & 21-Dec-2007 & -113 & 5 & 30-Apr-2013 & 5 & 5 & 23-Sep-2011 & 790 \\
\hline 6 & 05-Feb-2008 & 526 & 6 & 05-Jul-2013 & -138 & 6 & 10-Nov-2011 & 991 \\
\hline 7 & 07-May-2008 & 874 & 7 & 20-Sep-2013 & 60 & 7 & 21-Dec-2011 & -586 \\
\hline 8 & 22-Jun-2008 & -207 & 8 & 12-Oct-2013 & 0 & 8 & 22-Jan-2012 & -385 \\
\hline 9 & 07-Aug-2008 & -2870 & 9 & 23-Oct-2013 & -120 & 9 & 10-Mar-2012 & -290 \\
\hline 10 & 22-Sep-2008 & -1904 & 10 & 25-Nov-2013 & -63 & 10 & 05-Jun-2012 & -354 \\
\hline 11 & 07-Nov-2008 & -1817 & 11 & 11-Jun-2014 & 137 & 11 & 16-Jul-2012 & 516 \\
\hline 12 & 07-Feb-2009 & -1352 & 12 & 22-Jun-2014 & -89 & 12 & 24-Aug-2012 & 0 \\
\hline 13 & 25-Jun-2009 & -873 & 13 & 25-Jul-2014 & -179 & 13 & 21-Nov-2012 & 465 \\
\hline 14 & 10-Aug-2009 & -1138 & 14 & 07-Sep-2014 & 215 & 14 & 30-Dec-2012 & -539 \\
\hline 15 & 25-Sep-2009 & -764 & 15 & 29-Sep-2014 & 45 & 15 & 20-Mar-2013 & 647 \\
\hline 16 & 10-Nov-2009 & -621 & 16 & 10-Oct-2014 & 90 & 16 & 08-Jun-2013 & -294 \\
\hline 17 & 26-Dec-2009 & -391 & 17 & 21-Oct-2014 & 10 & 17 & 27-Aug-2013 & -191 \\
\hline 18 & 10-Feb-2010 & 0 & 18 & 01-Nov-2014 & -91 & & & \\
\hline 19 & 28-Jun-2010 & 206 & & & & & & \\
\hline 20 & 13-Nov-2010 & -281 & & & & & & \\
\hline 21 & 29-Dec-2010 & 675 & & & & & & \\
\hline 22 & 13-Feb-2011 & 1183 & & & & & & \\
\hline
\end{tabular}

In Fig.2, to compare velocity values obtained by the reference levelling and the estimated PS/DS result, a buffer of $300 \mathrm{~m}$ diameter centered on each groundwater abstraction station will be associated with a cluster of PS/DS. All the PS/DS inside this cluster were used to calculate the average velocity of the cluster. The correlation $R^{2}$ is higher 0.8 and the Root Mean Square Error (RMSE) is less than $5(\mathrm{~mm} / \mathrm{yr})$ for all ALOS PALSAR, TerreSAR-X and Cosmos SkyMed. In Fig. 3a, the joint distribution between
TerreSAR-X and Cosmos SkyMed is shown to appreciate the similarly significant rate. In Fig. $3 \mathrm{~b}$, to further validate results, we show a displacement history from the PS/DS analysis with with levelling data of buildings in a subsidence Hoang Mai area. The statistic result $\mathrm{R}^{2}=0.86$ and the RMSE is $4.0(\mathrm{~mm} / \mathrm{yr})$, confirming their good agreement. This is expected as compared with the previous works $[1,7]$. Hence, the PS/DS processing is effective to detect and estimate the subsidence phenomena. 
(a) Average vertical velocity $2007-2011$

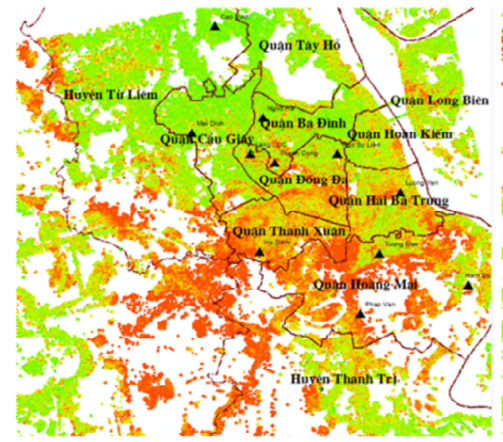

22 AlOs images (b) Average vertical velocity 2011-2013

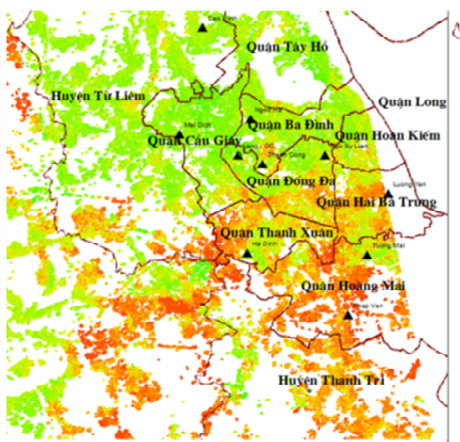

17 Cosmos skyMed images (c) Average vertical velocity $2012-2014$

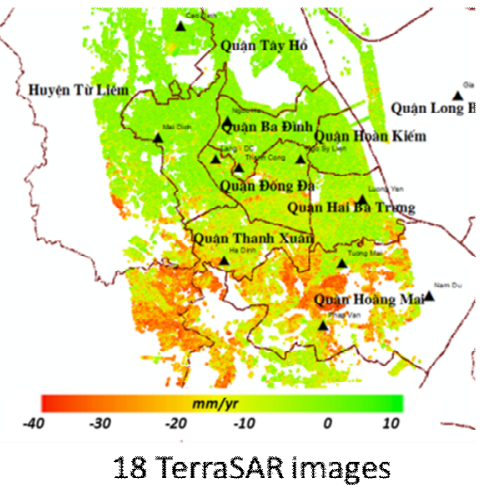

Figure 1. The average velocity trend. Positive velocities (green colors) represent movement uplift; negative velocities (red colors) represent movement subsidence.

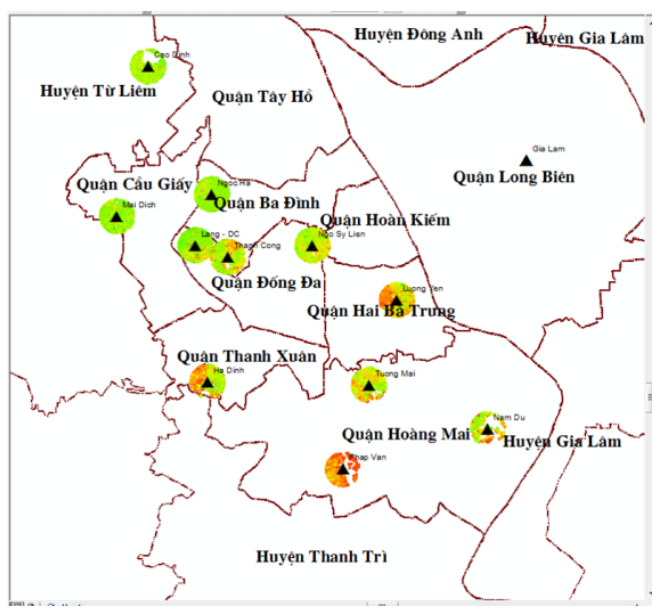

Figure 2. Hanoi in situ network at groundwater abstraction stations, see Fig. 1 for velocity legend.

(a) Joint distribution

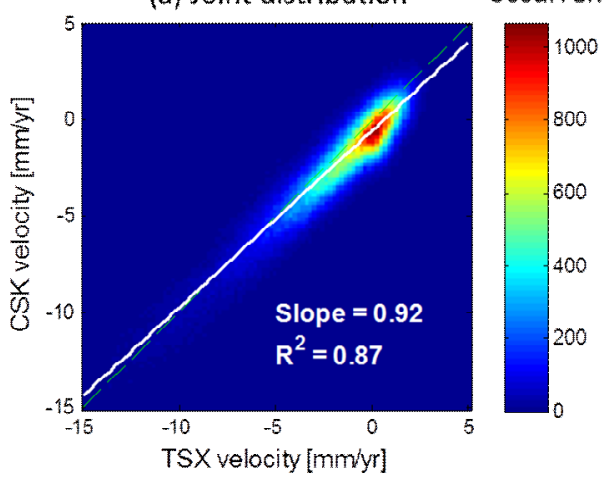

(b) Displacement history at CC7-UNH DAM

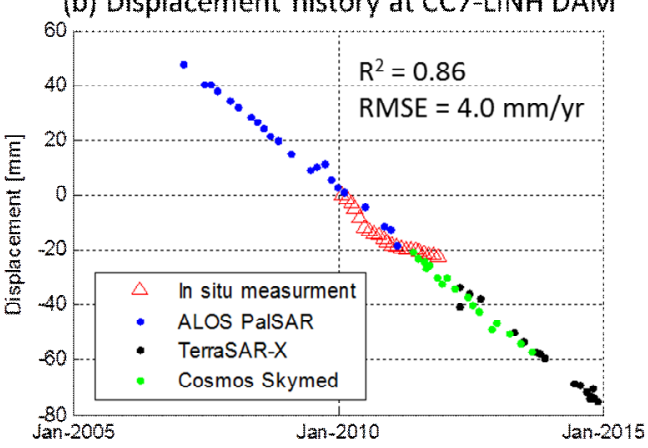

Figure 3. (a) Joint distribution between TSX velocity and CSK velocity. (b) The displacemend history retrieval at CC7-Linh Dam building, where the in situ measurment is available.

\section{Trang D6}




\section{DISCUSSIONS AND CONCLUSIONS}

In all three dataset, the ground subsidence phenomena was found mostly in the south of the city (Hoang Mai, Ha Dinh - Ha Dong, Thanh Xuan) at the thick soft soil layer of Haihung formation, which is quite similar to the geological loam and silt loam areas as in Ho Chi Minh City [1]. The north of city as Tay Ho, and north Tu Liem district is more stable. The issue can be explained by stable soil and Qp aquifer (Pleistocene aquifer) supported by the Red river. Thanh Cong area where is famous in Hanoi with ground subsidence was detected by SAR method.

The main reason of land subsidence of Hanoi can be divided into two main kinds. The first kind is natural reason and the other one is artificial reason. Natural reasons include modern fault, compact sediment, seasonal fluctuation of groundwater and soft soil layers. The artificial reasons include exploitation groundwater; loading capacity by building or levelling; dynamic loading by transportation or under construction building; and suffusion, quicksand negative skin friction [11]. Related to artificial reason, exploitation groundwater pumping wells is most affected.

There are a lot of studies about influence of groundwater exploitation to land subsidence of Hanoi [12,13]. [14] studied the land subsidence in Thanh Cong and Phap Van area by modelling. The study concludes that due to lack of land subsidence monitoring station, it cannot do mapping isocontour subsidence for whole of Hanoi inner city. During 2008-2009, [15] studied deformation of terrestrial by natural factors and mankind activities. It concludes that exploitation groundwater at Hadinh pumping station (Hadong) is main reason and the loading capacity by building is only secondary factor.
The geology stratigraphy is another important factor. The high risk of land subsidence in Hanoi occur only in area where exit the thick soft soil layer of Haihung formation. It is more dangerous if the soft layer overlay on exploited aquifer and in affected area by cone depression. In other area without or very thin soft soil layer, the maximum average subsidence speed only $10 \mathrm{~mm}$ per year with affected by pumping wells. The area which affected by lowering groundwater level of Qp aquifer (Pleistocene aquifer) is smaller in monsoon (August and September) and larger in dry season (March and April). From 1992 to 2006, the average area of cone depression expand 8,6 $\mathrm{km}^{2}$ per year [11]. [13] and [12] also confirmed the gradient groundwater level due to the influence of the groundwater pumping wells in Hanoi. [12] also proved the increasing difference between Holocene and Pleistocene groundwater levels from about $7 \mathrm{~m}$ in January 1995 to more than $10 \mathrm{~m}$ in December 2004 together with the distance to the Red River by studying many observation wells.

The ground deformation results from SAR of two periods 2007-2011 and 2011-2013/2014 in Hanoi describe exactly the subsidence area. Both results from Cosmos SkyMed and TerraSAR identified hot pot subsidence areas. But the results from Cosmos SkyMed data seem to be larger high velocity subsidence area than TerraSAR data (slope is 0.92). It needs to continue study and validation. By using PS/DS, not only subsidence history information but also average velocity of ground subsidence at Hanoi was detected. Particularly, at the moment, the metro lines are under-constructions and reducing exploitation ground water by Hanoi government. Therefore, combining PS/DS method and in-situ measurement is useful way for monitoring and predicting ground subsidence in Hanoi. 
To conclude, the average subsidence velocity map has been retrieved by PS/DS processing and the validation indicates good agreement with in situ data. This allows us to provide unprecedented spatial extent and continuous temporal coverage of the subsidence of the Hanoi city. The study shows that subsidence depends on the geology stratigraphy. Coupled with the human involvement, the subsidence problem simply becomes worse.
The authors would like to thank the Vietnam national science project DTDL.2012$\mathrm{T} / 28$ for funding this work. This work was also supported in part by IRSTEA. ALOS PALSAR images were provided by Japan Aerospace Exploration Agency under the framework of K\&C Phase 3. Thank to AN ASI/TELESPAZIO Company for the discount Cosmos SkyMed data of research project. Also thank to Airbus DS Geo Pte Ltd for co-operation in TerraSAR data.

\section{Xác định biến dạng lún khu vực Hà Nội bằng radar giao thoa}

- Hồ Tống Minh Định ${ }^{1}$

- Trần Quốc Cường ${ }^{2}$

- Nguyễn Đức Anh ${ }^{2}$

- Lê Toàn Thủy ${ }^{3}$

${ }^{1}$ Viện Khoa học và Công nghệ trong Môi trường và Nông nghệp (IRSTEA), Montepllier, Pháp

${ }^{2}$ Viện Khoa học địa chất, Viện Hàn lâm Khoa học và Công nghệ, Hà Nội, Việt Nam

${ }^{3}$ Trung tâm Sinh quyển (CESBIO), Toulouse, Pháp

\section{TÓM TẮT}

Quá trình đô thị hóa diễn ra rất nhanh trong giai đoạn thập niên cuối thế kỷ 20 đã dẫn đến hiện tuoong biến dạng lún mặt đất tại khu vưc thành phố Hà Nội, Việt Nam. Kỹ thuật radar giao thoa đa thờ gian (Persistent Scatters Interferometry - PSI) là mọt giải pháp khả thi nhất trong việc phát hiện các biến dạng bề mặt địa hình. Bài báo nhằm giới thiệu khả năng quan trắc biến dạng mặt đất của thành phố Hà Nội bằng kỹ thuật PSI, nhằm minh chứng ưng dụng công nghệ vũ tru là một giải pháp khả thi nhất trong việc phát hiện các biến dạng bề mặt địa hình theo không gian và thời gian. Kết quả được minh chứng khi so sánh giữa PSI và thủy chuẩn có độ tuoong quan là 0.86 và sai số là 4.0 mm/năm. Nghiên cưu cũng cho thấy biến dạng lún mặt đất xảy ra với mức độ nghiêm trọng ở nhũng vùng có tầng trầm tích Hải Hung phân bố ở phía nam thành phố. Khai thác ngầm quá mức và đô thị hóa là những tác nhân chính dẫn đến hiện tượng lún đất.

Tù khóa: Hà Nội, sụt lún, PS/DS, Irstea TomoSAR platform.

\section{Trang D8}




\section{REFERENCES}

[1]. Ho Tong Minh D., Le Van Trung and Le Toan T., Mapping Ground Subsidence Phenomena in Ho Chi Minh City through the Radar Interferometry Technique Using ALOS PALSAR Data. Remote Sens. (2015), 7, 8543-8562.

[2]. Ferretti A., Prati C. and Rocca F., Permanent Scatterers in SAR Interferometry, IEEE Transactions on Geoscience and Remote Sensing 39, 1 (2001), 8-20.

[3]. Ferretti, A. and Fumagalli, A. and Novali, F. and Prati, C. and Rocca, F. and Rucci, A., A New Algorithm for Processing Interferometric Data-Stacks: SqueeSAR, Geoscience and Remote Sensing, IEEE Transactions on 49, 9 (2011), 3460-3470.

[4]. Ramon F Hanssen, Radar Interferometry: Data Interpretation and Error Analysis (2001).

[5]. Richard Bamler and Philipp Hartl, Synthetic aperture radar interferometry, Inverse Problems (1998), R1-R54.

[6]. Paolo Berardino and Gianfranco Fornaro and Riccardo Lanari and Eugenio Sansosti, A New Algorithm for Surface Deformation Monitoring Based on Small Baseline Differential SAR Interferograms, IEEE Transactions on Geoscience and Remote Sensing (2002), 2375-2383.

[7]. Rocca, F., Modeling Interferogram Stacks, Geoscience and Remote Sensing, IEEE Transactions on 45, 10 (2007), 3289-3299.

[8]. Ho Tong Minh, D., Thuy Le Toan, Fabio Rocca, Stefano Tebaldini, Mauro Mariotti d'Alessandro and Ludovic Villard., Relating P-band Synthetic Aperture Radar Tomography to Tropical Forest Biomass, Geoscience and Remote Sensing, IEEE Transactions on (2014), 967-979.
[9]. Ho Tong Minh, D., Tebaldini, S., Rocca, F., Le Toan, T., Villard, L. and DuboisFernandez, P.C., Capabilities of BIOMASS Tomography for Investigating Tropical Forests, Geoscience and Remote Sensing, IEEE Transactions on (2015), 965-975.

[10].Ho Tong Minh, D., S. Tebaldini, F. Rocca, T. Koleck, P. Borderies, C. Albinet, L. Villard, A. Hamadi and Le Toan T., Ground-Based Array for Tomographic Imaging of the Tropical Forest in P-Band, Geoscience and Remote Sensing, IEEE Transactions on (2013), 4460-4472.

[11].Lieu T. M, Hazard in Engineering geology, urban environment of $\mathrm{Ha}$ Noi and fundamental for mitigation solutions, Proceeding of International Conference for anniversary 1000 years Thang Long - Ha Noi, Sustainable development Hanoi (2010), 1049-1062.

[12].Jusseret, S. and Baeteman C. and Dassargues A., The stratigraphical architecture of the quaternary deposits as support for hydrogeological modelling of the central zone of Hanoi, Geol. Belg. 13 (2010), 77-90.

[13].Thu, T.T and Fredlund, D.G, Modelling subsidence in the Hanoi city area, Can. Geotech (2000), 621-636.

[14].Nhan, P. Q., Research potential groundwater of Hanoi area, retrograde reserves and quality groundwater, built-up oriental strategy exploit..., Research project code 010-04/09-2008-2 (2008).

[15].Tu, T. V., Assessment ground deformation and building by natural activities and economy of Hadong city and surround Hatay province, Research project supported by Government of Hatay province (2009). 